\title{
Greves e negociação coletiva do funcionalismo público federal brasileiro de 1995 a 2010
}

\author{
Strikes and collective bargaining in the federal civil service from 1995 to 2010
}

\author{
Pedro Augusto Ponce \\ Doutorando em Ciência Política \\ Universidade Federal de São Carlos - bolsista FAPESP \\ e-mail: pedro.cso@gmail.com
}

\section{Eduardo Garuti Noronha}

Professor do Programa de Pós-Graduação em Ciência Política

Universidade Federal de São Carlos

e-mail: enoronha@uol.com.br
Recebido: 28/04/2013

Aceito: 07/07/2013

\begin{abstract}
RESUMO Este artigo tem como tema as greves e os processos de negociação coletiva do setor público brasileiro, buscando as razões para o aumento da duração média das paralisações no funcionalismo público federal nos governos FHC (1995-2002) e Lula (2003-2010). Segundo dados coletados no Departamento Intersindical de Estatísticas e Estudos Socioeconômicos e apresentados pela literatura de greves constatou-se a partir de 1999 um aumento expressivo no número de horas paradas no setor público federal de 170 horas paradas em 1999 até atingir 5896 horas paradas em 2006. Dado que o volume das greves (número de greves, grevistas e de Jornadas Não Trabalhadas) permaneceu estável durante o período, o aumento das horas paradas indica que as greves tornaram-se mais difíceis de serem negociadas. Partimos da hipótese de que a maior duração média das greves do setor público federal no período decorre de problemas nos processos de negociação entre a administração pública federal e os sindicatos.
\end{abstract}

PalaVRas-ChaVe Greves; Negociação coletiva; Setor público federal.

ABSTRACT This article focuses on strikes and collective bargaining processes of Brazilian's public sector, seeking the reasons for the increasing in the average duration of strikes in the federal civil service in the FHC government (1995-2002) and Lula (2003-2010). According to data collected in Departamento Intersindical de Estatísticas e Estudos Socioeconômicos and presented by the strike's literature, was noticed that from 1999 happened an expressive increase in the downtime in the federal public sector from 170 hours without working in 1999 until reach 5896 hours without working in 2006. Since the volume of strikes (number of strikes, strikers and Days not Worked) remained stable during the period, the increasing downtime indicates that the strikes had become more difficult to be traded. Our main assumption is that the increased average during strikes in the federal public sector is related with problems in the negotiation process between the Federal government and the unions.

KEYWORDS Strikes; Collective bargaining; Federal public sector. 


\section{Greves no Setor Público Brasileiro}

Este artigo trata das greves do funcionalismo público federal nos governos FHC (1995-2002) e Lula (2002-2010). Dados coletados no SAG - Sistema de Acompanhamento de Greves - do Departamento Intersindical de Estatísticas e Estudos Socioeconômicos (Dieese, 2005) e apresentados pela literatura de greves, mostraram que, a partir de 1997, com o final do primeiro grande ciclo de greves (1978-1997) ${ }^{1}$ as greves do setor público brasileiro crescem mais, são mais numerosas e demoram mais do que as do setor privado. A busca de explicações para esse fenômeno deve necessariamente levar em consideração o "estado da arte" das relações de trabalho do setor público brasileiro, ou seja, suas formas de organização, as disposições legais e os mecanismos de resolução de disputas que caracterizam a relação entre os atores em questão ao longo do período analisado. Além disso, comparações internacionais quanto a outras formas de relação de trabalho e negociação coletiva auxiliarão no entendimento das peculiaridades do caso brasileiro. Também não devem ser desconsideradas as mudanças ocorridas na forma de organização sindical ao longo do período e como se relacionam aos processos políticos e econômicos. A partir do levantamento destas questões pretende-se construir uma hipótese de pesquisa a saber, o aumento do número de Horas Paradas $^{2}$ no funcionalismo público brasileiro, com o foco nos funcionários do setor público federal deve-se a problemas nos processos de negociação das greves.

Parto de uma linha de estudos nacionais e internacionais de greves. Entre os autores internacionais ressaltamos os trabalhos de Birke (2007), Ferner e Hyman (1992b), Locke (1999), Shalev e Korpi (1979), Shalev e Korpi (1980), Tilly (1974), Tilly (1978), Zapata (1986), Zapata (1987) e Zapata (2007). Estes estudos são marcos importantes do comportamento das greves e da negociação coletiva no plano internacional. Dentre os estudos nacionais destacam-se os trabalhos de Abramo (1986), Noronha (1992), Noronha e Gebrin (1998) e Noronha (2009) COSTA. Neste estudo ressaltamos o que Noronha (2009) chama de "Primeiro Grande Ciclo Brasileiro de

\footnotetext{
${ }^{1}$ Partindo de uma concepção cíclica do fenômeno grevistas, os trabalhos do autor são marcos no estudos de greves no Brasil principalmente quando analisou a importância das greves na transição politica brasileira. Ver Noronha (2009).

${ }^{2}$ Noronha (2009) em seus trabalhos utiliza o indicador Jornadas Não Trabalhadas (JNTs) que são, segundo o autor o indicador mais sintético de uma greve. E calculado a partir da somatória da multiplicação do número de trabalhadores de cada greve pelo número de dias parados em um determinado período de tempo. Quando trata-se de volume de greves esse indicador mostra-se ser o mais eficiente. Nesta pesquisa, diferentemente, busco saber porque está havendo uma maior duração media das greves, dessa forma o principal indicador utilizado é o número de Horas Paradas em cada greve anualmente.
}

Greves" iniciado com as paralisações dos metalúrgicos do ABC paulista, tendo seu auge na década de 1980 e caindo nos anos 1990. Segundo esses estudos, as greves do ciclo e sua excepcionalidade se vincularam ao pacto de transição política para a democracia. Após 1997, com o final do ciclo as paralisações entram no que o autor chama de "normalidade", com estabilidade dos indicadores em ambos os setores. Esses estudos são marcos importantes no entendimento da natureza do conflito e das distintas formas de organização e atuação dos setores público e privado no Brasil.

Neste artigo ressalto as principais diferenças nas formas de organização e de atuação dos atores de ambos os setores no pais. Essas diferenças são percebidas tanto nas leis que regem as formas de organização trabalhista, no comportamento das greves e nos processos de negociação coletiva. Concluo afirmando o caráter multilateral e a natureza estritamente política das relações de trabalho no setor público brasileiro, diferenciando-se da unilateralidade das relações típicas do setor privado. Isso pode ser percebido tanto pela multiplicidade de atores e interesses das relações de trabalho do setor público como pela natureza das paralisações e as razões que explicam suas eclosões.

Embora explicite as diferenças entre os setores chamo a atenção para o fato de que, como afirma Cheibub (1999: p. 15), nas últimas décadas “[...] uma série de transformações políticas e econômicas internacionais diminuíram gradativamente a importância analítica da distinção entre o setor público versus privado". Um exemplo dessas "transformações políticas e econômicas" em nível nacional foi o projeto de lei enviado pelo governo federal durante o primeiro mandato do presidente Fernando Henrique, visando um maior ajuste fiscal e regulamentando pontos da Emenda Constitucional da reforma administrativa, aprovada em 1995. Entre os projetos encaminhados, um visava disciplinar o emprego público, fazendo com que a grande maioria dos servidores públicos fosse regida pela CLT. (o projeto excluía poucas categorias típicas e exclusivas do Estado, que continuariam sendo regidas por regime estatutário).

As restrições orçamentárias, necessárias para o combate ao déficit fiscal, tornaram-se quase tão draconianas quanto às restrições de mercado. Politicamente, observou-se mundo afora maior consciência dos cidadãos e dos governos com os gastos públicos. Os símbolos desse movimento foram às revoltas contra impostos e as demandas por máquinas públicas enxutas e eficientes que tiveram lugar em diversos países, inclusive no Brasil. (Cheibub, 1999: 119)

Ainda, segundo o autor, o traço mais característico da distinção entre os setores sempre foi a determinação 
unilateral do Estado das condições de remuneração e trabalho dos servidores públicos. Segundo ele, nas ultimas décadas essa doutrina tem sido substituída pela "[...] prática da consulta institucionalizada e da negociação coletiva [...]" (Cheibub, 1999).

No Brasil embora a Constituição assegure o direito de associação sindical, não há nenhuma lei que obrigue o Estado a negociar com os sindicatos ou uma política que institucionalize as relações entre o governo e essas organizações. Segundo Cheibub (1999) essa falta de institucionalização das relações de trabalho no setor público dificulta os procedimentos de negociação e propicia uma imprevisibilidade na relação entre os atores. Isso se deve, como afirma o autor, a natureza multilateral das relações de trabalho no setor público. Segundo aponta Tsebelis (1998), uma relação unilateral é aquela correspondente a dois atores em jogo, enquanto a multilateral é composta por $n$ atores.

Acreditamos que a maior demora na resolução dos conflitos pode estar relacionada pela natureza multilateral das relações do setor público e por não ser um "jogo de soma zero". Segundo a teoria dos jogos um jogo de soma zero é aquele em que para que um ator atinja seus objetivos o outro tem necessariamente que perder, ou seja o payoff $f^{\beta}$ total para todos os jogadores, em cada combinação de estratégias, sempre somam zero (um jogador sempre lucra com o prejuízo de outro).

Segundo Tsebellis (1998):

$\mathrm{Na}$ teoria dos jogos, os jogadores enfrentam uma série de opções (estratégicas); quando cada um escolhe uma estratégia, os jogadores determinam juntos o resultado do jogo, recebendo os payoffs associados a esse resultado. Para encontrar a solução de um problema, a teoria dos jogos sustenta que as regras do jogo (que determinam as estratégias disponíveis) e os payoffs dos jogadores são fixos. Uma vez fixada as regras e os payoffs, os atores escolhem estratégias ótimas para si mesmos; cada jogador escolhe uma estratégia que maximize o seu payoff, levando em conta o que os outros jogadores fazem. (Tsebellis, 1998: 22).

Acredito que os processos de negociação das greves no setor público não caracterizam um jogo de soma zero, pela própria natureza multilateral ( $n$ atores e interesses) dessas relações, o que torna o cálculo da soma zero complicado. Primeiro porque as relações entre os atores nesse setor são intrinsecamente políticas, ou seja, em um processo de negociação

\footnotetext{
Utilizamos o termo payoff, segundo definido por Tsebellis (1998) que significa o ganho, o pagamento, o prêmio ou a sanção a uma certa ação. Em um jogo de soma zero o payoff total é sempre zero pois se o ator A ganhar uma quantidade $n$ por exemplo, o ator B tem de necessariamente perder $-n$. Dessa forma, a soma dos ganhos é sempre zero.
}

pode-se ter pressões em momentos eleitores, líderes sindicais pressionando por cargos políticos, ou utilizarem a opinião pública para obterem maiores benefícios. Além de que, se conseguem resolver o impasse, a aprovação do acordo deve ser votada nos poderes legislativos municipais, estaduais ou federais, onde a pluralidade de atores e interesses é ainda maior. Em segundo lugar, pois diferentemente da área privada, o serviço público não visa o lucro, tem-se uma receita, oriunda de tributos arrecadados ou de outras formas de captação de recursos, como projetos dos governos estaduais e federais. Nem mesmo na área privada, caracterizada por ser uma relação unilateral, a perda de um ator significa necessariamente a vitória de outro, pois há diversos mecanismos de correção das perdas no mercado que tornam o cálculo de soma zero complexo.

No entanto, acredito que em momentos de crise econômica em que as administrações públicas são obrigadas a fazer ajustes fiscais, tem-se uma estrutura mais próxima de um jogo de soma zero, onde de um lado o governo busca o ajuste fiscal e de outro os sindicatos lutando para manter níveis de empregos e salários. A Lei Complementar $n^{\circ} 101$, de 4 de maio de 2000 na seção II (Brasil, 2000) "Do Controle da Despesa Total com Pessoal" estabelece as normas de finanças públicas voltadas para responsabilidade na gestão fiscal. Segundo o artigo abaixo, o ente federativo que não cumprir com os dispositivos da Lei de Responsabilidade Fiscal sofrerá sanções conforme dispõe o art.23 da Lei Complementar 101 de maio 2000.

Art. 23. Se a despesa total com pessoal, do Poder ou órgão referido no art. 20, ultrapassar os limites definidos no mesmo artigo, sem prejuízo das medidas previstas no art. 22, o percentual excedente terá de ser eliminado nos dois quadrimestres seguintes, sendo pelo menos um terço no primeiro, adotando-se, entre outras, as providências previstas nos $\S \S 30$ e 40 do art. 169 da Constituição.

$\S 1$ o No caso do inciso I do § 3o do art. 169 da Constituição, o objetivo poderá ser alcançado tanto pela extinção de cargos e funções quanto pela redução dos valores a eles atribuídos. (Vide ADIN 2.238-5).

§ 20 É facultada a redução temporária da jornada de trabalho com adequação dos vencimentos à nova carga horária. (Vide ADIN 2.238-5).

§3o Não alcançada a redução no prazo estabelecido, e enquanto perdurar o excesso, o ente não poderá: I - receber transferências voluntárias; II - obter garantia, direta ou indireta, de outro ente; III - contratar operações de crédito, ressalvadas as destinadas ao refinanciamento da dívida mobiliária e as que visem à redução das despesas com pessoal. (Lei Complementar $\mathrm{N}^{\circ} 101$, 2000) (Lei Complementar, 2000: p.23). 
Em tese, podemos supor que essa lei produz efeitos na demora das negociações, ou sendo resolvidas mais rapidamente, pois os sindicatos já sabem até onde podem negociar, ou fazendo com que demorem mais, quando os sindicatos não aceitam a proposta do governo e o impasse continua. Nesse artigo temos por objetivo entender o funcionamento de um processo de negociação coletiva repleto de atores e interesses.

Greves tem uma natureza complexa e ocorrem devido a uma série de variáveis explicativas que não cabem ser analisadas aqui. Deve-se salientar que nem sempre as greves no setor público ocorrem visando salário e melhoria das condições de trabalho dos trabalhadores, podem também ter objetivos políticos indiretos, como pressionar o governo em períodos eleitorais por exemplo. A pesquisa terá como pressuposto o apontado por Noronha (2009), que no Brasil as greves ocorrem não quando os salários são percebidos pelos trabalhadores como baixos ou mesmo adequados, mas sim quando as lideranças sindicais percebem momentos oportunos para o ganho. $\mathrm{O}$ autor parte desse pressuposto analisando a alta incidência de greves em períodos de crescimento econômico.

Segundo afirmado por Cheibub (1999), que analisou a relação entre o governo federal e as Entidades Associativas do setor público no processo de reforma administrativa que ocorreu no primeiro governo FHC, sob o comando do então ministro da Administração Federal e Reforma do Estado - MARE, Luiz Carlos Bresser Pereira, a construção de um processo de cooperação entre o governo e as EAs no Brasil foi condicionada e limitada pela baixa institucionalização dos canais de interação entre eles e por processos políticos e organizacionais que caracterizam a dinâmica interna dos atores governamentais e dos atores associativos. Segundo ele, interesses e estruturas organizacionais dificultam a definição de estratégias uniformes e de linhas de ação coerentes entre os atores.

O Brasil, durante as décadas de 1980 e 90 estava vivendo um período de crise fiscal do Estado e crise financeira, o que favorecia uma negociação do tipo de um jogo de soma zero entre os atores do setor público, uma situação em que há uma dificuldade para uma relação cooperativa entre eles. Segundo Cheibub (1999) esses anos são marcados pela inexistência de um canal permanente, institucionalizado e dedicado exclusivamente ao tratamento das questões trabalhistas no setor público.

Tal situação é causada devido a dois fatores. Primeiramente, devido a situação geral das relações de trabalho no setor público e pela situação específica da constituição dessas relações no Brasil. Cheibub
(1999) afirma que é preciso diferenciar, de um lado os "determinantes estruturais" e as situações históricas e de outro aspectos organizacionais como os mecanismos que caracterizam a interação entre os atores.

No que se refere aos determinantes estruturais, podemos destacar uma série de questões de cunho político, econômico e ideológico internacionais que diminuíram a distinção entre público e privado. $\mathrm{Ou}$ seja, a crise de um modelo de Estado, que seguindo décadas de expansão no pós-guerra na Europa, enquanto provedor de saúde, educação e seguridade social, e que gerou um intenso debate sobre a sobrecarga e crise fiscal do Estado e da esfera pública. Segundo (Ferner e Hyman, 1992a) essas tendências de longo prazo foram também agravadas pelos efeitos de uma crise econômica que conduziu a piora dos déficits do setor público nos anos 1970.

Segundo o autor (Ferner e Hyman, 1992a) essas tendências encorajaram uma ampla resposta política nos anos 1980, que chama de "roll back the State". As pressões de reforma do Estado começaram a surgir a partir da Integração Europeia e mais geralmente do aumento da competitividade internacional. $\mathrm{Na}$ Europa o "roll back of the State", tomou duas formas. Primeiro, o governo redefiniu as áreas de ação do Estado, redesenhando certas atividades por meio das privatizações por exemplo e segundo tentando reformar a disposição dos serviços públicos, o que, segundo o autor, trouxe uma radical mudança na maneira com que a administração pública é gerenciada. Isso impôs ao setor público um estilo e uma estrutura de gerenciamento típicas do setor privado: em outras palavras, o "mercado penetrou no núcleo do Estado"(Ferner e Hyman, 1992a).

O autor (Ferner e Hyman, 1992a) também aponta para um debate sobre o crescimento da convergência entre o Estado e as relações industriais do setor privado. Afirma que isso deve-se a introdução de modelos do setor privado de negociação coletiva e a representação da força de trabalho em países onde a doutrina da soberania unilateral do Estado predomina.

Uma das formas encontradas internacionalmente para resolver os problemas fiscais do Estado tem sido o que Cheibub (1999) chama de "[...] privatização das relações de trabalho no setor público". Ou seja, um abandono de um conceito de governo enquanto um empregador soberano em favor de abordagens mais consensuais nas quais se permite que as organizações de empregados públicos tenham um grau maior de voz. (Cheibub, 1999). Assim, acredito que uma mudança no plano ideológico, de uma perda de hegemonia do keyneyzianismo e sua substituição pela doutrina do equilíbrio fiscal, são centrais para o entendimento 
da natureza política das relações de trabalho no setor público. Por fim o Brasil das décadas 1980 e 90 estava vivendo um período de crise fiscal do Estado e crise financeira, o que favorecia uma negociação do tipo de um jogo de soma zero entre os atores do setor público, uma situação em que há dificuldade para uma relação cooperativa entre os atores.

\section{Mecanismos de Resolução de Conflitos}

A negociação coletiva do setor público é um processo que envolve de um lado o governo (políticos e administradores públicos) e de outro entidades sindicais. Os primeiros poderiam agir de acordo com dois tipos de estratégias: uma centrada no corte de custos via dispensa de funcionários e terceirização e, em segundo, tratando a questão do trabalho como um recurso, segundo Cheibub (1999) - um ativo que pode ser mobilizado e envolvido no processo e nas negociações de cortar os custos. Isso se dá, hora buscando a participação do sindicato na negociação ou tentando neutralizá-los, buscando a adesão individual dos trabalhadores em detrimento de suas representações coletivas. As entidades sindicais por sua vez ou seguem uma rota mais cooperativa ou optam por uma estratégia confrontacionista.

Outro ponto que merece destaque, como aponta Sussekind (1999, p. 46), é referente a regulamentação do direito de greve para o setor público no Brasil. O direito de greve para o serviço público é garantido pela Constituição Federal de 1988, segundo o art. 37, inciso VII (Brasil,1988: 12), segundo o qual "[...] será exercido nos termos e nos limites definidos em lei complementar". Embora ainda necessite de regulamentação por parte do Congresso Nacional, ao qual cabe a aprovação da lei para regulamentar o direito, em 2007 o Supremo Tribunal Federal (STF) julgou que enquanto não se regulamentar o dispositivo constitucional que garanta o direito de greve para o funcionalismo público, vale a lei 7.783/89 da Constituição Federal que regulamenta a greve para o serviço privado. Assim o STF julgou e estendeu aos trabalhadores públicos a aplicação dessa lei que regulamenta o direito de greve para o setor privado.

O regime jurídico de trabalho brasileiro pode ser estatutário ou celetista, sendo que o último foi idealizado para normatizar a relação entre capital e trabalho (na qual o trabalhador é hipossuficiente), no âmbito de uma organização que visa lucro. No entanto, para a administração pública o regime celetista não se compatibiliza. Dentre as inaplicações desta lei podemos citar como exemplo a figura do FGTS - Fundo de Garantia por Tempo de Serviço (Brasil, 1990), que tem por objetivo proteger o trabalhador em caso de dispensa sem justa causa. Nesse caso, o empregador dispensa o funcionário sem ter uma causa e tem de pagar uma multa de $40 \%$ sobre o FGTS.

$\mathrm{Na}$ área pública não há dispensa imotivada. $\mathrm{O}$ servidor público, como denomina a Constituição Federal, (Brasil,1988: 12), acessa ao cargo ou emprego público e pode se tornar estável após três anos de efetivo exercício, tornando-se vitalício, caso comprove sua adaptação à área pública. Para que o servidor seja dispensado é necessário ter um motivo e resguardar o direito a ampla defesa, mediante processo de sindicância e dependendo da gravidade de processo administrativo disciplinar. Nas administrações públicas onde existe o regime celetista várias leis são editadas para contemplar direitos, de cunho estatutário, como adicionais por tempo de serviço, cessões para outros órgãos públicos, dentre outros.

Não há legislação específica regulando as negociações entre o Estado e seus servidores no Brasil. As relações de trabalho no setor público federal- com exceção das empresas públicas federais, são estatutárias. Isso significa que há uma adesão dos trabalhadores a lei que regulamenta o serviço público e não uma negociação coletiva entre o governo e os sindicatos. Ou seja, não existe regulamentação de mecanismos de disputas, seja elas individuais ou coletivas. Essas disputas, segundo afirma Cheibub (1999) geralmente são resolvidas por processos administrativos e pela promulgação unilateral de leis e decretos pelo governo. Não há nenhuma norma legal que obrigue o Estado a negociar com o sindicato (diferentemente do que acontece no setor privado).

No setor público tem-se o direito de associação sem o compromisso com a negociação. Na prática tem-se no Brasil a chamada "data-base" - um período do ano em que os patrões e empregados se reúnem para repactuar os termos de seus contratos coletivos de trabalho. A data-base de uma categoria é o equivalente ao primeiro dia de aquisição dos direitos trabalhistas.

Conforme afirmado:

A configuração estrutural permite e, na verdade, incentiva os atores envolvidos a evadir os termos da negociação direta e buscar alianças com outras forças políticas não diretamente envolvidas nas negociações. Do lado sindical, há uma constante busca de apoio e influência sobre o Legislativo para impor decisões e/ ou mudar decisões tomadas no Executivo. Os negociadores do lado governamental podem sempre apelar para um poder decisório superior ao seu e para a transferência de responsabilidade nas decisões. Essa condição estrutural torna ainda mais premente a institucionalização de canais e procedimentos de negociação, com o intuito de tornar mais previsíveis as negociações trabalhistas no setor público. (Cheibub, 1999: 121). 
A raiz do problema de pesquisa colocado aqui busca primeiramente identificar que em um quadro de crise fiscal do Estado, desemprego e crise econômica, em que de um lado tem-se o Estado, inserido em processo de reforma administrativa e enxugamento de despesas e de outro sindicatos lutando para manter níveis salariais e de emprego, a maior demora nos processos negociativos trabalhistas deve-se a falta de canais e mecanismos institucionalizados de negociação e devido a multiplicidade de atores e interesses envolvidos nas negociações.

A partir de 2003, no governo Lula, embora o número de greves e de grevistas ter a partir de 1997 entrado em uma estabilidade (como mostra a Figura 2), os dados apontam para um vertiginoso aumento do número de horas paradas principalmente no setor público, o que decorreu da maior duração média das greves. A duração das greves no setor público federal subiram de 170 horas paradas em 1999 para 5896 horas paradas em 2006 e sofrem um declínio a partir de 2006, como mostra a Figura 1.

O mapeamento dos canais e mecanismos de negociação e de como os atores se reconhecem enquanto legítimos no processo de negociação ajudarão a entender porque, desde 1997, tem havido um crescimento vertiginoso no número greves e de horas paradas no setor público federal. Esse aumento é acentuado a partir de 2003 com o primeiro governo Lula, como pode ser observado no Tabela 2.

Para tanto parte-se de duas hipóteses de pesquisa. Primeiramente de que a maior demora nas paralisações se dá porque há problemas nos processos de negociação entre o Estado e os sindicatos. Partimos da suposição de que isso está relacionado a inexistência de um canal permanente, institucionalizado e exclusivamente dedicado ao tratamento de questões trabalhistas no

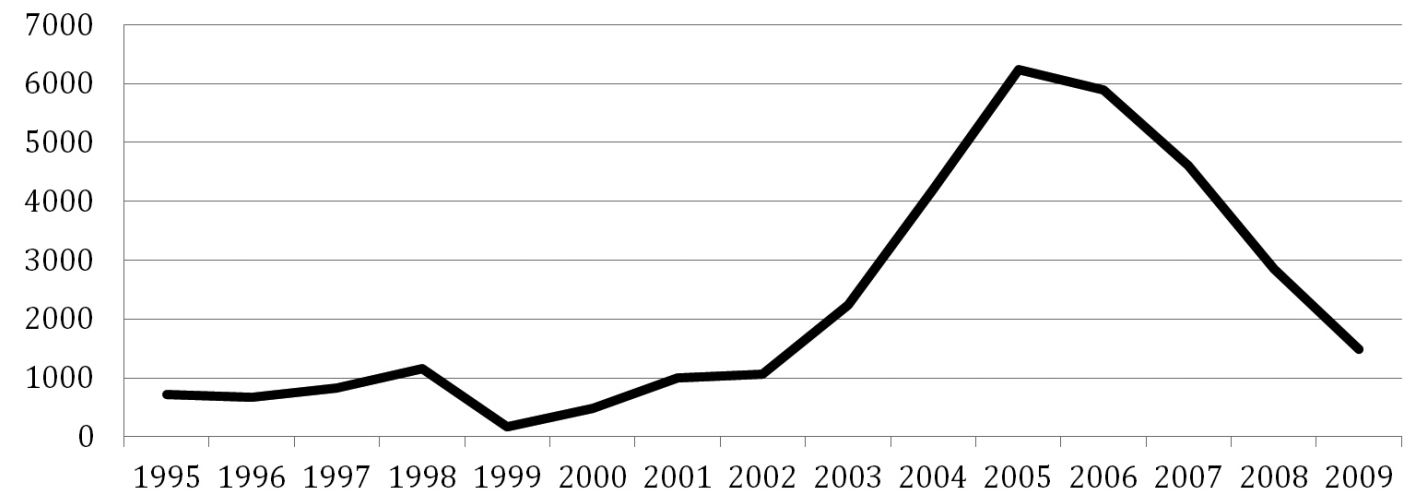

GFHP

Figura 1. Greves do funcionalismo público federal por Horas Paradas.
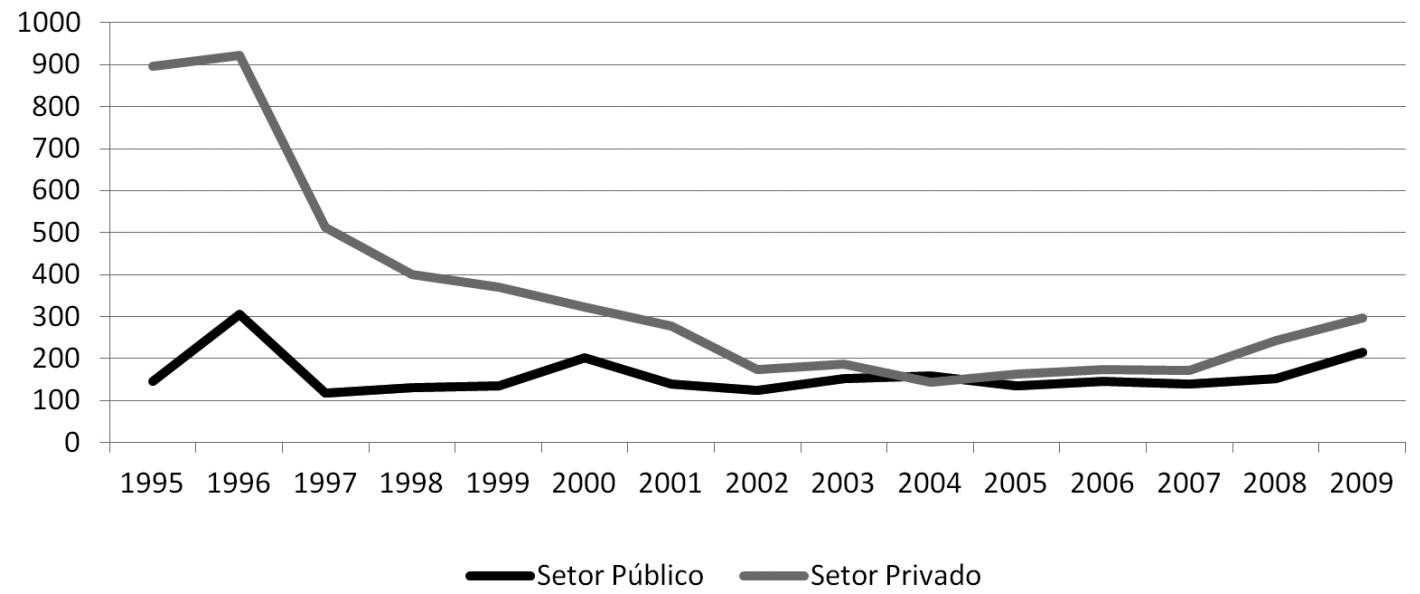

Figura 2. Número de Greves por setor de ati. 
setor público e de condições mais gerais das relações de trabalho nesse setor. Em segundo lugar, buscaremos a comprovação da hipótese de que, no Brasil, as lideranças sindicais optam por fazer greves quando percebem momentos oportunos para o ganho. Para tanto utilizamos dados que apontam para altos índices de greves em momentos de prosperidade econômica e de que isso pode estar vinculado ao que Noronha (2009) chama de "contaminação dos ganhos" de uma esfera ou categoria para outra. Para a consecução dos objetivos serão realizadas entrevistas com lideres sindicais e com membros da administração pública federal, além da localização e motivação das paralisações ao longo do período.

Nesta pesquisa, embora não tenha pretensões de um trabalho comparativo entre os setores público e privado, utilizamos as comparações com o setor privado enquanto um guia ou espelho para a análise no que diz respeito a aspecto legais, a negociação coletiva e ao comportamento das greves ao longo dos anos.

Como apontado por Cheibub (1999) quase a totalidade dos países da OCDE (Organização de Cooperação para o Desenvolvimento Econômico) negocia com seus servidores públicos e/ou pratica alguma forma de consulta ou negociação coletiva institucionalizada para a determinação de remuneração e de condições de trabalho.

Na França por exemplo, há negociação coletiva centralizada, que resulta em recomendações para o governo, que tem o poder de recusá-las. Segundo afirma Cheibub (1999), para que o governo aceite é necessário regulamentação ou decreto e na ausência de acordo o governo pode estabelecer unilateralmente a remuneração. No caso americano a remuneração é excluída da negociação coletiva para a maioria dos servidores federais e a lei federal permite negociação sobre condições de trabalho. E no caso da Espanha negociações centralizadas determinam os salários dos servidores públicos. O autor afirma que em contraposição aos casos citados, em países em desenvolvimento ainda predomina a delimitação unilateral pelo Estado.

Após o final de um ciclo de greves na década de 1990, os dados apontam para uma estabilidade do volume de greves em ambos os setores, principalmente a partir de 1997, embora o número de Horas Paradas no setor público subir vertiginosamente de ano para ano em todas as categorias. (ver Tabelas 1 e 2) e declinar a partir de 2006. Durante o ciclo (1978-1997) a excepcionalidade nos níveis de conflito vinculavam-se a um pacto de transição para a democracia, que segundo Noronha (2009) ocorreu por meio de eleições e greves. As greves após o final do ciclo assumem a característica que assumem em todos os países democráticos industrializados, um “[...] instrumento coletivo de pressão e negociação do elo mais fraco da relação entre empregados e empregadores". (Noronha, 2009: p. 15). Os fatores responsáveis pelo aumento expressivo na duração das greves deve-se, como explicamos aqui, a falta de institucionalização e de mecanismos de negociação coletiva do setor público brasileiro. Isso devido ao caráter estritamente político das greves e das negociações trabalhistas no setor e de que o sucesso das demandas trabalhistas no setor público depende muitas vezes do apoio aos eleitores e da defesa de expansão do Estado e de seus orçamentos.

$\mathrm{O}$ entendimento das variações nos indicadores de greves ao longo de dois governos tão diversos do ponto de vista político e econômico e naturalmente da forma com que estabelece diálogos com outros atores abre um leque de questões sobre como se dá e como podemos melhorar um processo de cooperação e interação entre os atores. Ressalto mais uma vez que o relacionamento entre os atores (governo, sindicatos, partidos políticos) no setor público não é um jogo de soma zero, onde o ganho de um ator simplesmente significa a perda de outro. Dessa forma a pesquisa leva em consideração a natureza estritamente política das greves e do processo de negociação do setor público brasileiro, seus múltiplos atores e interesses envolvidos.

Estabeleceu-se esse recorte de pesquisa primeiro pela lógica diferente de atuação entre nos primeiros e segundo mandatos de cada governo e em segundo pois acreditamos que um dos fatores que explica o aumento da duração das greves no funcionalismo público federal é a distancia física entre as esferas de decisão e negociação e pela maior visibilidade das greves do funcionalismo público federal. Também optamos por não levar em consideração as greves dos funcionários das empresas estatais, pois seu padrão de atuação assemelha-se a greves do setor privado. De acordo com o banco de dados do SAG do Dieese (2005), entre os motivos das paralisações estão aquelas categorizadas como "greves de advertência" que são paralisações rápidas, com tempo determinado. Essas greves foram consideradas na análise pois, de acordo com uma verificação preliminar dos dados, não influenciam no aumento da duração das greves.

Nesse estudo utilizamos o número de Horas Paradas e não o índice "Jornadas Não Trabalhadas"4 utilizado pela literatura de greves. Isso porque, em

\footnotetext{
4 Jornadas Não Trabalhadas é um indicador de greves que é calculado a partir da multiplicação do numero de trabalhadores de cada greve pelo número de dias parados. É segundo Noronha (2009) o indicador mais sintético das greves.
} 
primeiro lugar, de acordo com os objetivos propostos, optou-se por isolar o numero de grevistas da análise e focar somente no aumento de horas não trabalhadas.
Em segundo pois há paralisações em que não há informações sobre o número de grevistas envolvido, o que dificultaria o calculo das JNTs.

Tabela 1. Número de Greves por setor de atividade.

\begin{tabular}{|c|c|c|c|c|c|}
\hline \multirow[b]{2}{*}{ CATEGORIA } & \multicolumn{4}{|c|}{ NÚMERO DE GREVES } & \multirow[b]{2}{*}{ TOTAL } \\
\hline & $\begin{array}{l}\text { 1995-1998 } \\
\text { (FHC) }\end{array}$ & $\begin{array}{l}\text { 1999-2002 } \\
\text { (FHC) }\end{array}$ & $\begin{array}{c}\text { 2003-2006 } \\
\text { (LULA) }\end{array}$ & $\begin{array}{l}\text { 2007-2009 } \\
\text { (LULA) }\end{array}$ & \\
\hline Auxiliares de Administração Escolar & 0 & 3 & 3 & 7 & 13 \\
\hline Empregados do Banco Central & 4 & 4 & 10 & 3 & 21 \\
\hline Enfermeiros profissionais & 2 & 5 & 3 & 2 & 12 \\
\hline Funcionalismo Público federal* & 19 & 11 & 34 & 4 & 68 \\
\hline Fundações e Instituições Federais - INSS & 4 & 5 & 15 & 9 & 33 \\
\hline Fundações e Instituições Federais - CVM & 0 & 3 & 0 & 1 & 4 \\
\hline Fundações e Instituições Federais - Imprensa Nacional & 0 & 5 & 0 & 0 & 5 \\
\hline Fundações e Instituições Federais -ANVISA & 0 & 1 & 4 & 0 & 5 \\
\hline $\begin{array}{l}\text { Fundações e Instituições Federais -Orquestra Sinfônica } \\
\text { Brasileira }\end{array}$ & 0 & 1 & 0 & 0 & 1 \\
\hline Fundações e Instituições Federais - INCRA & 0 & 1 & $5 * *$ & 0 & 6 \\
\hline Fundações e Instituições Federais - DNIT & 0 & 0 & 1 & 3 & 4 \\
\hline $\begin{array}{l}\text { Fundações e Instituições Federais - Fundação Osvaldo } \\
\text { Cruz }\end{array}$ & 3 & 3 & 1 & 1 & 8 \\
\hline Fundações e Instituições Federais - IBGE & 2 & 0 & 3 & 0 & 5 \\
\hline Fundações e Instituições Federais - IBAMA & 0 & 0 & 2 & 3 & 5 \\
\hline Fundações e Instituições Federais - FUNAI & 0 & 0 & 1 & 0 & 1 \\
\hline Fundações e Instituições Federais - FUNDACENTRO & 1 & 0 & 0 & 0 & 1 \\
\hline Fundações e Instituições Federais - INPI & 1 & 0 & 0 & 0 & 1 \\
\hline Fundações e Instituições Federais - INPS & 1 & 0 & 0 & 0 & 1 \\
\hline Fundações e Instituições Federais - CNEN & 1 & 0 & 1 & 0 & 2 \\
\hline Médicos da Rede Federal & 1 & 1 & 3 & 0 & 5 \\
\hline Poder Executivo Federal & 0 & 0 & 8 & 18 & 26 \\
\hline Poder Judiciário Federal & 3 & 11 & 11 & 2 & 27 \\
\hline Poder Legislativo Federal & 3 & 0 & 0 & 0 & 3 \\
\hline Polícia Federal & 0 & 1 & 5 & 12 & 18 \\
\hline $\begin{array}{l}\text { Professores Rede Federal de Ensino Fundamental e } \\
\text { Médio }\end{array}$ & 1 & 1 & 0 & 0 & 2 \\
\hline Professores Rede Federal de Ensino Superior & 13 & 2 & 3 & 0 & 18 \\
\hline Rede Federal de Ensino Superior e Técnico & 1 & 2 & $5 * * *$ & 0 & 8 \\
\hline Rede Pública Federal de Ensino & 1 & 1 & 0 & 0 & 2 \\
\hline Rede Pública Federal de Saúde & 0 & 3 & 0 & 0 & 3 \\
\hline TOTAL & 61 & 64 & 118 & 65 & 308 \\
\hline
\end{tabular}

*Nesse item não há no banco de dados do SAG - DIEESE maiores informações sobre qual categoria efetuou as paralisações. **Greve em conjunto entre as categorias dos funcionários do IBAMA e INCRA em 4.05.2006. ${ }^{*} *$ Greve conjunta entre a categoria dos Professores da Rede Federal de Ensino Superior e de Ensino Técnico em 01.04.2004. 
De acordo com as tabelas observa-se primeiramente um aumento de quase o dobro no número de greves no primeiro governo Lula, em comparação com o período anterior. (a partir do número total de greves, registrou-se 46,1\% delas no segundo governo FHC e 53,9\% no primeiro governo Lula). Esse aumento é

Tabela 2. Número de Horas Paradas por setor de atividade.

\begin{tabular}{|c|c|c|c|c|c|}
\hline \multirow[b]{2}{*}{ CATEGORIA } & \multicolumn{4}{|c|}{ NÚMERO DE HORAS PARADAS } & \multirow[b]{2}{*}{ TOTAL } \\
\hline & $\begin{array}{l}\text { 1995-1998 } \\
\text { (FHC) }\end{array}$ & $\begin{array}{l}\text { 1999-2002 } \\
\text { (FHC) }\end{array}$ & $\begin{array}{c}\text { 2003-2006 } \\
\text { (LULA) }\end{array}$ & $\begin{array}{c}2007-2009 \\
(\text { LULA) }\end{array}$ & \\
\hline Auxiliares de Administração Escolar & 0 & 48 & 1.416 & 984 & 2.448 \\
\hline Empregados do Banco Central & 21 & 90 & 579 & 372 & 1.062 \\
\hline Enfermeiros profissionais & 16 & 48 & 176 & 32 & 272 \\
\hline Funcionalismo Público federal* & 922 & 704 & 4.992 & 96 & 6.714 \\
\hline Fundações e Instituições Federais - INSS & 88 & 160 & 1.744 & 537 & 2.529 \\
\hline Fundações e Instituições Federais - CVM & 0 & 32 & 0 & 16 & 48 \\
\hline Fundações e Instituições Federais - Imprensa Nacional & 0 & 480 & 0 & 0 & 480 \\
\hline Fundações e Instituições Federais -ANVISA & 0 & 32 & 704 & 0 & 736 \\
\hline $\begin{array}{l}\text { Fundações e Instituições Federais -Orquestra Sinfonica } \\
\text { Brasileira }\end{array}$ & 0 & 24 & 0 & 0 & 24 \\
\hline Fundações e Instituições Federais - INCRA & 0 & 24 & 320 & 0 & 344 \\
\hline Fundações e Instituições Federais - DNIT & 0 & 0 & 40 & 216 & 256 \\
\hline Fundações e Instituições Federais - Fundação Oswaldo Cruz & 32 & 72 & 16 & 8 & 128 \\
\hline Fundações e Instituições Federais - IBGE & 16 & 0 & 616 & 0 & 632 \\
\hline Fundações e Instituições Federais - IBAMA & 0 & 0 & 344 & 504 & 848 \\
\hline Fundações e Instituições Federais - FUNAI & 0 & 0 & 8 & 0 & 8 \\
\hline Fundações e Instituições Federais - FUNDACENTRO & 8 & 0 & 0 & 0 & 8 \\
\hline Fundações e Instituições Federais - INPI & 488 & 0 & 0 & 0 & 488 \\
\hline Fundações e Instituições Federais - INPS & 16 & 0 & 0 & 0 & 16 \\
\hline Fundações e Instituições Federais - CNEN & 8 & 0 & 0 & 0 & 8 \\
\hline Médicos da Rede Federal & 8 & 24 & 240 & 0 & 272 \\
\hline Poder Executivo Federal & 0 & 0 & 3.144 & 2.984 & 6.128 \\
\hline Poder Judiciário Federal & 18 & 488 & 960 & 408 & 1.874 \\
\hline Poder Legislativo Federal & 168 & 0 & 0 & 0 & 168 \\
\hline Polícia Federal & 0 & 8 & 664 & 0 & 672 \\
\hline Professores Rede Federal de Ensino Fundamental e médio & 72 & 8 & 0 & 0 & 80 \\
\hline Professores Rede Federal de Ensino Superior & 192 & 56 & 1.416 & 0 & 1.664 \\
\hline Professores Rede Federal de Ensino Superior e Técnico & 688 & 8 & 1.264 & 0 & 1.960 \\
\hline Rede Pública Federal de Ensino & 840 & 8 & 0 & 0 & 848 \\
\hline Rede Pública Federal de Saúde & 0 & 340 & 0 & 0 & 340 \\
\hline TOTAL & 3.601 & 2.654 & 18.643 & 6.157 & 31.055 \\
\hline
\end{tabular}

*INSS - Instituto Nacional de Seguridade Social; CVM - Comissão de Valores Mobiliários; ANVISA - Agencia Nacional de Vigilância Sanitária; INCRA - Instituto Nacional de Colonização e Reforma Agraria; DNIT - Departamento Nacional de Infraestrutura de Transporte; IBGE - Fundação Instituto Brasileiro de Geografia e Estatística; IBAMA - Instituto Brasileiro do Meio Ambiente e dos Recursos Naturais Renováveis; FUNAI - Fundação Nacional do Índio; INPI - Instituo Nacional de Propriedade Industrial; INPS - Instituto Nacional de Previdência Social; CNEN -Comissão Nacional de Energia Nuclear. 
percebido em quase todas as categorias com exceção dos funcionários da área de saúde (enfermeiros e rede pública federal de saúde) e de ensino (professores da rede federal de ensino médio, superior e técnico e rede pública federal de ensino), que tiveram um número maior de greves no governo FHC.

No entanto o maior número de greves dessas duas categorias na administração FHC não é seguido por um maior número de HPs. Na área de saúde por exemplo, a categoria dos enfermeiros profissionais, embora tenham feito um número menor de greves no governo Lula, ficaram parados por muito mais tempo (um aumento de $366 \%$ em relação ao período anterior). Também registrou-se um aumento de HPs na Imprensa Nacional que efetuou 5 greves no governo FHC e nenhuma no governo Lula porém com um baixo número de horas paradas $(2,25 \%$ do total de HPs).

Os funcionários do poder judiciário federal, embora tenham feito quase o mesmo número de greves em ambos os governos, registrou-se um aumento de 196,7\% em comparação com o período anterior. Há também setores que fizeram um número baixo de greves porém com uma acentuada elevação no número de HPs, como é o caso dos auxiliares da administração escolar das quais o número de HPs foi 2.950 vezes maior que no período anterior. Por fim, podemos destacar também as greves feitas pela categoria de funcionários públicos federais do INSS. Nessa categoria registrou-se tanto o aumento de greves (das quais $75 \%$ delas feitas no governo Lula) quanto de HPs, que foram 1090 vezes maior que no período anterior.

Essas avaliações prévias dos dados evidenciam dificuldades dos governos nos processos de negociação das greves e/ou reações das categorias a determinadas políticas de governo, o que deverá ser acompanhado por um mapeamento detalhado da agenda dos dois governos no período em questão.

\section{Quantitativo de Servidores Públicos Federais}

Podemos identificar quatro diferentes conjunturas quanto a evolução do estoque de servidores civis federais no Brasil, que podem ser caracterizados de acordo com a evolução do número de servidores ativos, aposentados e pensionistas anualmente. Destacamos como primeira fase os anos 1991-1994, que caracterizam-se por ser um período de crise e estagnação. Esse período é marcado pela constante tentativa de reforma do Estado promovidas pelo governo Collor e pelas tentativas de uma reforma previdenciária.
O processo de reforma administrativa engendrado no governo Collor foi responsável por um profundo rearranjo estrutural. Nesse sentido, em detrimento de um ideal orçamentário, extinguiu e fundiu ministérios promovendo uma redução da máquina pública. Costa (2008) identifica as concepções de Estado que estavam presentes no período da reforma, aponta as contradições do modelo e analisa os objetivos e resultados. O autor (Costa, 2008) identifica por um lado as medidas orientadas para o aumento da eficiência e a redução de gastos e por outro, tendo como propósito reduzir a interferência do Estado no domínio econômico, a extinção de empresas, fusão de ministérios e privatizações. Embora o governo Itamar (1992-1994) tenha concentrado esforços na valorização dos servidores com melhorias salariais, não se cuidou da ampliação do ingresso de pessoal por concurso público.

A segunda conjuntura corresponde ao primeiro mandado do governo FHC, entre 1995-1999. Esse período é marcado por uma reforma "gerencialista", orientada predominantemente por valores de eficiência e qualidade na prestação de serviços públicos e pelo desenvolvimento de uma cultura gerencial nas organizações.

A reforma administrativa do governo $\mathrm{FHC}$ provocou duas importantes mudanças quanto ao efetivo de funcionários públicos. Em primeiro lugar promoveu a restruturação do que Nogueira (2005) chama de "carreiras estratégicas do Estado", buscando aplicar práticas gerenciais modernas nas empresas públicas com uma ênfase no "empreendedorismo público" que tem por requisitos a gestão de pessoal e a flexibilização de vínculo. Nesse sentido registrou-se em 1995, um aumento de 20 mil novos servidores no que diz respeito a essas carreiras e no final do quadriênio 106 mil servidores haviam deixado o governo enquanto 46 mil novos haviam ingressado nas carreiras estratégicas do Estado.

Por outro lado, a reforma do governo FHC provocou uma redução acentuada no quadro de funcionários públicos do poder executivo e um aumento no quadro de funcionários do poder legislativo e judiciário, como mostra o Tabela 1 . No poder executivo houve uma diminuição de 951.585 em 1995 para 841.850 em 1998 e continuou caindo até chegar a 809.975 no final do segundo mandato. No final do segundo mandato em 2002 registrou-se uma redução de $14,88 \%$ do quadro de funcionários ativos do poder executivo.

Na Figura 3 podemos observar o ingresso no setor público federal por concurso público segundo nível

\footnotetext{
As carreiras típicas são entendidas aqui como sendo as atividades de fiscalização, arrecadação tributária, previdenciária e do trabalho, controle interno, segurança pública, diplomacia e defensoria pública.
} 


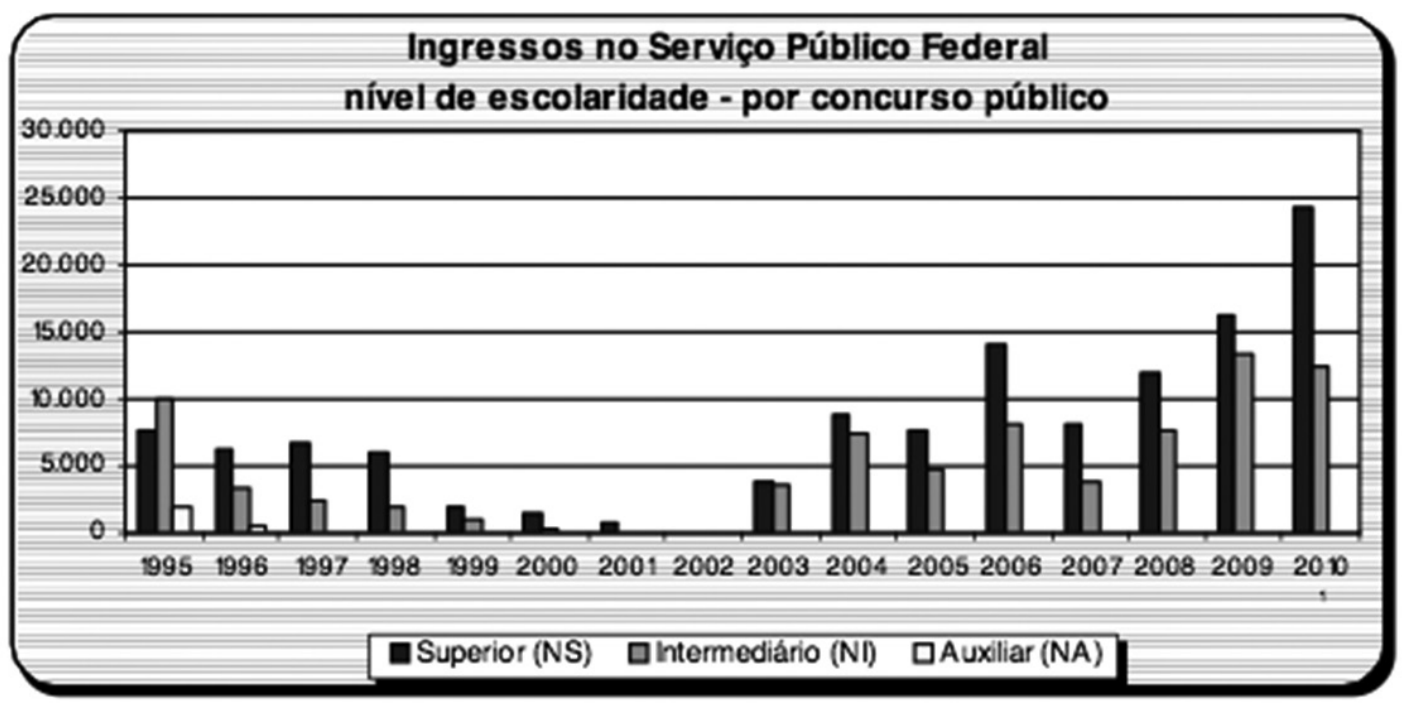

Figura 3. Ingresso no Serviço Público Federal por nível de escolaridade. http://www.planejamento.gov.br/secretarias/upload/ Arquivos/servidor/publicacoes/boletim_estatistico_pessoal/2011/Bol177_Jan2011.pdf

de escolaridade. Observa-se que ao longo da década de 1990 houve um acentuado declínio, passando a aumentar a partir de 2003 com o governo Lula. A partir de 2003 o governo foca-se em contratar e abrir vagas para os níveis superior e intermediário, enquanto não se verifica contratações no nível auxiliar, o que indica que esta categoria foi em sua maioria terceirizada.

Cabe destacar também que nesse período estava em tramite no Congresso Nacional a reforma do sistema previdenciário que veio estabelecer uma série de novas regras para a aposentadoria incluindo os servidores públicos, segundo a Emenda Constitucional de n. $20^{6}$ que modifica o sistema de previdência social e estabelece normas de transição entre outras

\footnotetext{
${ }^{6}$ Sobre o sistema de previdência a Lei 9717 de 27/11/1998 dispõe sobre as regras gerais para a organização e o funcionamento dos regimes próprios de previdência social dos servidores públicos da União, dos Estados, do Distrito Federal e dos municípios, dos militares dos estados e do Distrito Federal (DF).

A lei 9783, de 28/01/1999 dispõe também sobre a contribuição para o custeio da previdência social dos servidores públicos, ativos e inativos e dos pensionistas dos três poderes da União.

O INT/Orçamento e gestão/SEAP n ${ }^{\circ} 5$ - D.O estabelece as regras para aposentadoria, tempo de contribuição, aposentadoria por invalidez, permanente, compulsória, voluntária, especial, integral, das regras do direito adquirido - todos decorrentes da Emenda Constitucional $\mathrm{n}^{\circ} 20$. PRT/Orçamento e Gestão SRH 5 DE 13/05/1999 dá a orientação sobre o recolhimento da contribuição social do servidor publico ocupante de cargo efetivo, do aposentado e do pensionista e as hipóteses de isenção.

Por fim, a orientação normativa /MOG/SRH/DENOR $n^{\circ} 9$ de 17/05/1999 dispõe sobre a não aplicação do limite máximo do salário maternidade as ocupantes apenas de cargos de comissão (artigo 14 da Emenda Constitucional $n^{\circ} 20$ )

Fonte: http://legislacao.planalto.gov.br/legisla/legislacao.nsf/ Viw_Identificacao/emc\%2020-1998?OpenDocument
}

providências, o que acredito promover mudanças no quadro de funcionários da união.

A terceira conjuntura refere-se ao segundo mandato do governo FHC em meio a uma crise cambial e fiscal iniciada em 1999. Segundo Nogueira (2005) nesse período as preocupações com a contenção de gastos chegaram a afetar a reforma de Estado, cujo modelo de implementação dependia de gastos de custeio, além de representar um ônus político devido a resistência dos servidores.

Cabe ressaltar alguns aspectos que segundo Costa (2008), dificultam um processo de reforma administrativa: entre eles estão a sólida institucionalização dos elementos a serem reformados, a resistência organizada de setores afetados, o surgimento de consequências inesperadas, a existência de interesses e objetivos diversos e conflitantes, a falta de foco na mudança por parte dos atores estratégicos, as incertezas, ambiguidades inerentes a mudança, o deslocamento de objetivos.

Do ponto de vista econômico a reeleição do presidente Fernando Henrique Cardoso, buscou viabilizar uma política que evitasse a aceleração inflacionaria e também preservasse a abertura comercial e financeira. Sua política econômica buscou combinar metas de inflação, superávit primário nas contas do governo e taxa de cambio flutuante. A taxa de cambio flutuante expressava a continuidade de uma política cambial o que significava que o país continuava a renunciar ao poder de usar a taxa de cambio como instrumento para orientar o desenvolvimento e para exportar mais produtos 
manufaturados e depender menos de importações desses produtos.

Segundo Baltar et al. (2010), buscando evitar a fuga de capitais, elevou-se a taxa de juros em um nível muito elevado antes da desvalorização do Real, e depois da desvalorização do real a taxa de juros foi mantida num patamar muito elevado. Assim a desvalorização do Real tendia a ter um impacto positivo na atividade da economia brasileira, ao viabilizar uma maior exportação a ao permitir melhores condições para que os produtores nacionais pudessem competir com os produtos importados. Assim, a contenção dos gastos públicos e as altas taxas de juros visavam a manutenção de um reduzido nível de atividade econômica, como forma de impedir a aceleração inflacionária.

As altas taxas de juros conduziam a uma tendência de crescimento da divida pública maior do que a do crescimento do PIB. Segundo os autores (Baltar et. al., 2010) o superávit primário nas contas públicas tinham como objetivo evitar o aumento desproporcional da divida pública, para tanto houve um aumento expressivo da carga tributária, em especial das contribuições sociais (aumento que vinha ocorrendo desde os anos 1990 em consequência da implementação do esquema de contribuições sociais previsto pela Constituição Federal que criou um sistema de seguridade social no país).

O total de impostos e contribuições sociais aumentou de cerca de $25 \%$ para $35 \%$ do PIB. Além da criação da Lei de Responsabilidade Fiscal, o que facilitou a ação do tesouro no sentido de conter as despesas e de investimento e tornar-se capaz de pagar uma parte dos juros.

Do período de 1999 a 2003, a política macroeconômica adotada conseguiu conter o aumento da inflação, provocando um pequeno crescimento do PIB, alcançado principalmente pelos impactos do comércio com outros países. Segundo apontam os autores Baltar et. al. (2010), a moeda permaneceu desvalorizada nesse período e o desempenho da economia mundial piorou em 2001. No entanto foi possível compensar o fraco desempenho do mercado com o aumento das exportações e da redução das importações, de tal modo que foi possível a reversão do saldo comercial deficitário da década de 1990, conseguindo superávit em 2002.

Registrou-se assim pouco menos de $5 \mathrm{mil}$ servidores que ingressaram por concurso público no poder executivo nos 4 primeiros anos. O número de aposentados também aumentou acentuadamente nos três poderes. No poder executivo aumentou de 483.228 aposentados para 519.398, o que representa um aumento de 6,9\%, como mostra os Tabela 3.
No segundo mandato (de 1999 a 2002) houve uma pequena diminuição de aposentados, que passaram de 527.355 para 516.12, o que representa uma pequena diminuição de $1,5 \%$.

Ao longo dos dois mandatos do governo FHC registou-se uma queda 141.610 funcionários públicos do poder, o que representa uma queda de $14,88 \%$ no quadro de funcionários do poder executivo, sendo que 133.798 saíram do quadro entre aposentados e pensionistas. No entanto, os poderes legislativo e judiciário não seguem a mesma tendência. Nessas esferas registrou-se um aumento no quadro de funcionários ativos. No poder legislativo houve um aumento de 17.402 funcionários em 1995 para 20.501 no último ano de governo. No judiciário o aumento é ainda mais expressivo, passando de 64561 para 81716 mil funcionais em 2002.

Ao compararmos o número de horas paradas do poder judiciário federal ao longo do período notamos um aumento expressivo tanto no número quanto na duração das greves. No que diz respeito ao número de horas paradas do poder judiciário federal, elas passaram de 18 horas paradas no primeiro mandato FHC, para 488 horas paradas no final do governo. No primeiro governo Lula esse número cresce ainda mais, quase dobrando o número de horas paradas da categoria, como mostram as Tabelas 1 e 2 .

A mesma relação também pode ser percebida ao compararmos o quantitativo de funcionários públicos federais e os índices grevistas das greves deflagradas pelas Fundações (ver Tabelas 2 e 3). Ao compararmos o efetivo de funcionários das fundações com a quantidade e horas paradas das greves nota-se que o aumento segue a orientação de outras categorias. Ou seja, um pico de horas paradas no primeiro governo Lula, em um momento em que o efetivo de funcionários crescia vertiginosamente.

Embora possamos destacar elementos importantes na política macroeconômica entre os governos FHC e Lula, há também diferenças importantes como por exemplo a perda do ímpeto do processo de privatizações de empresas estatais e o fortalecimento do Banco Nacional de Desenvolvimento Econômico e Social (BNDES). Entre as continuidades podemos citar por exemplo as políticas de metas de inflação e de cambio flexível, adotadas pelo Banco Central após a desvalorização do real em 1999, e a de superávit primário implementada pelo Ministério da Fazenda. Segundo apontam Baltar et al. (2010) essa desvalorização alterou significativamente o quadro de funcionários da economia brasileira e sua relação com o mercado de trabalho.

A quarta conjuntura refere-se ao primeiro mandato do governo Lula, a partir de 2003, que é caracterizada pela nova expansão do contingente de servidores públicos federais. No ano de 2003 e 2004 o número 


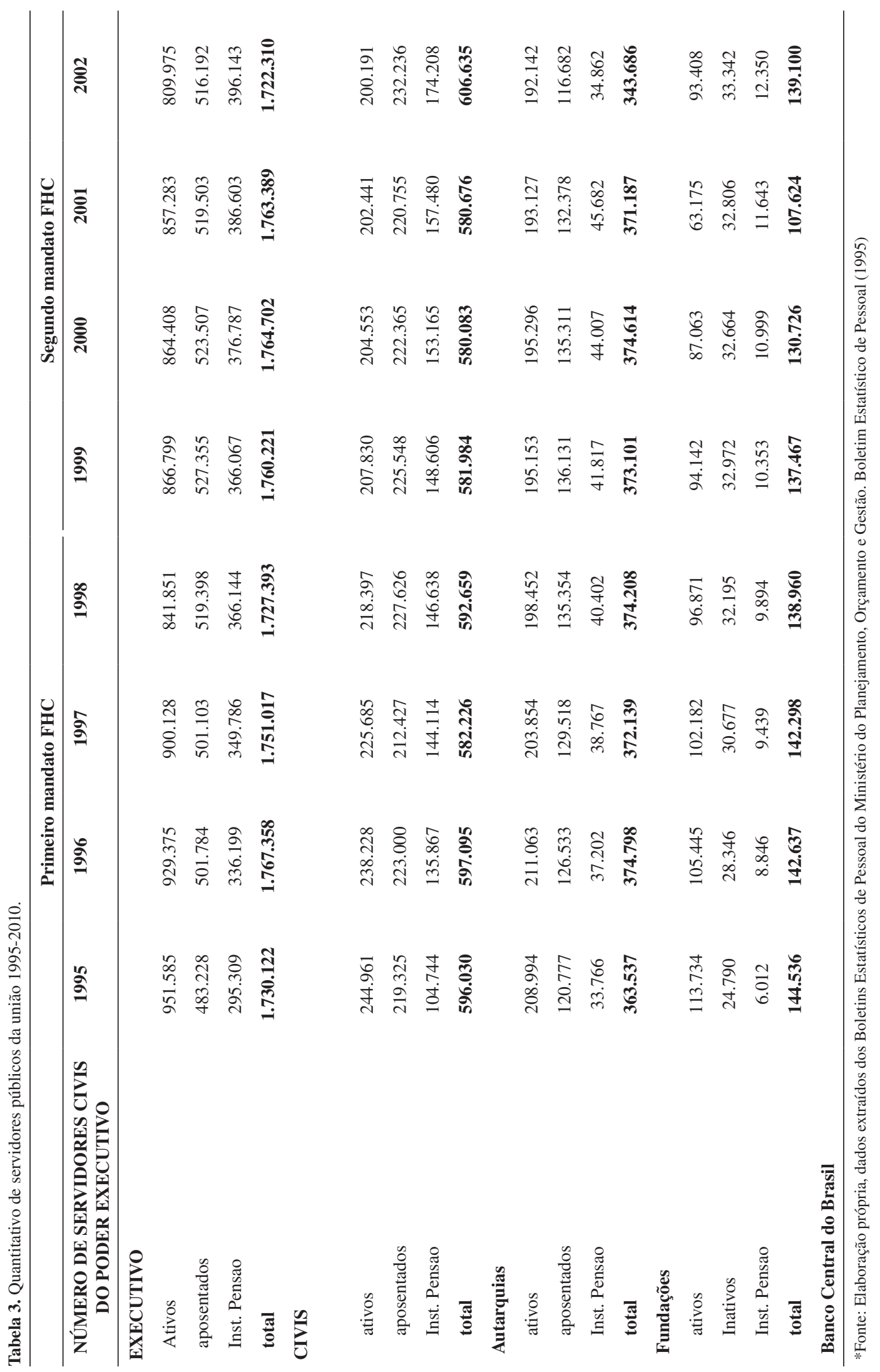




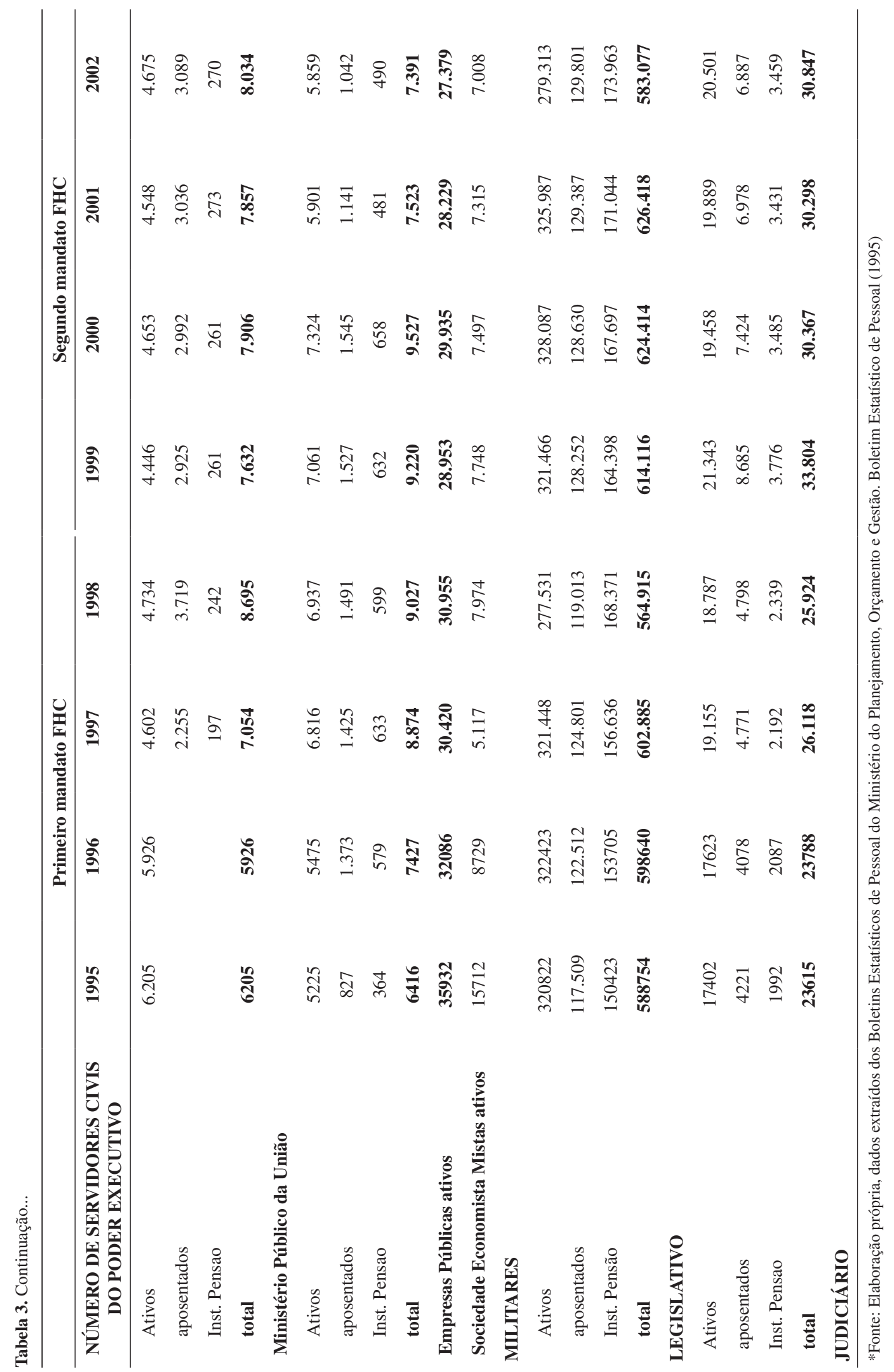




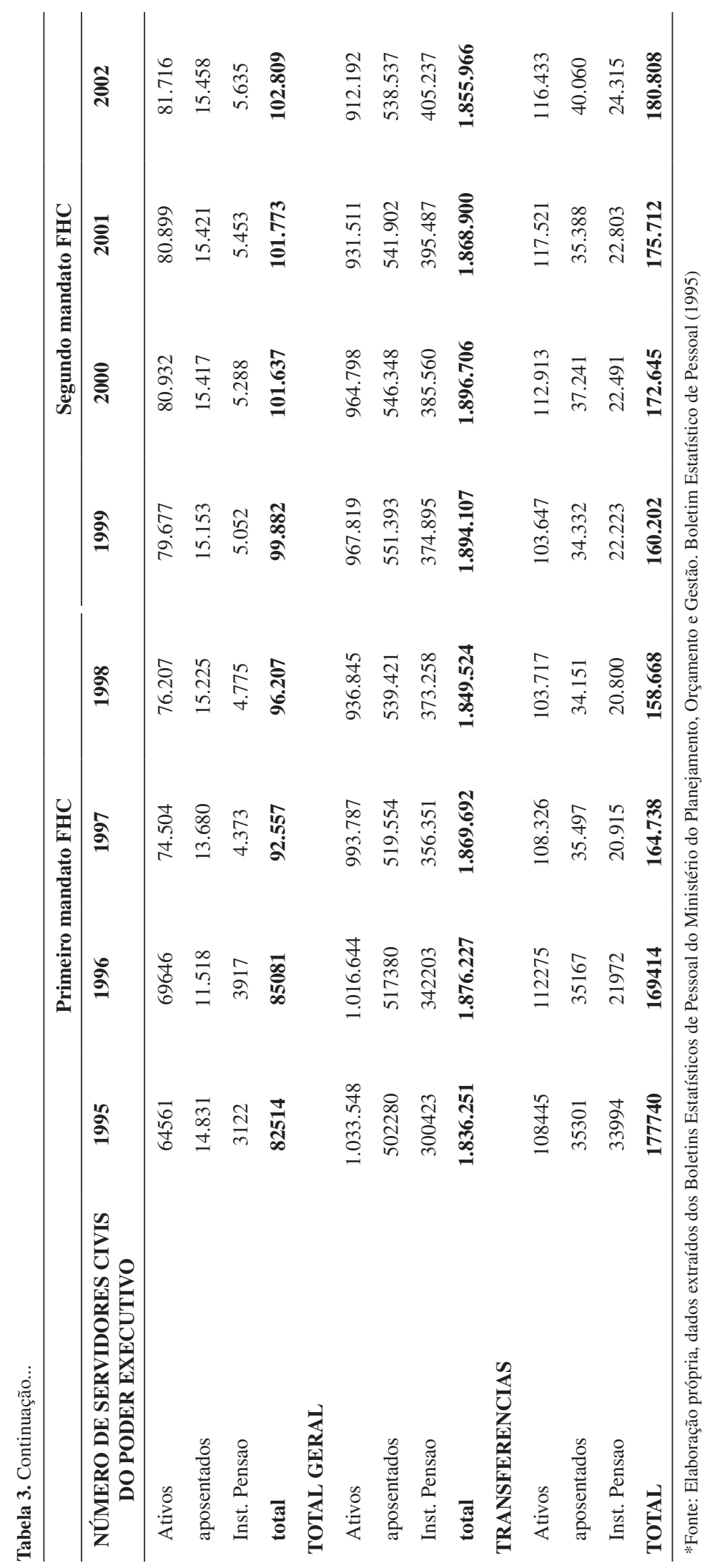


de funcionários ativos poder executivo passou de 856.236 para 884.091. O aumento também ocorreu nos poderes legislativo e judiciário como podem ser observados na Tabela 3.

$\mathrm{O}$ autor defende que a atividade de planejamento estratégico de pessoal do setor público nunca assumiu sua devida importância em nenhum das conjunturas apontadas acima. No governo FHC subestimou-se a pressão por demandas por recursos humanos que seriam criadas pela nova política gerencial, incluindo o perfil das agências reguladoras, a despeito de, segundo o autor (Nogueira, 2005), não estarem claramente previstas no Plano Diretor da Reforma do Estado em 1995.

Quanto ao governo Lula, Nogueira (2005) aponta o número de vagas abertas para concurso público em 2003 e 2005, o que é extremamente interessante se compararmos com o número de greves e de horas paradas da mesmas categorias no período. Segundo ele:

- 39\% das vagas referem-se a funções docentes e de apoio das instituições de ensino do ministério da educação;

- $15 \%$ das vagas são de servidores do sistema da Previdência Social;

- $12 \%$ são de servidores de funções do Ministério da Justiça;

- 9\% referem-se a funções do Ministério da Fazenda;

- $6 \%$ referem-se as novas carreiras relacionadas com agencias reguladoras federais nas áreas e de comunicação, saúde, energia elétrica entre outros;

- $63 \%$ das vagas foram destinadas a cargos de Nível Superior;

- 37\% destinadas a cargos de nível intermediário.

Com relação ao número de vagas para as instituições de ensino, o objetivo do governo era de suprir pessoal permanente e regular para funções que vinham sendo exercidas por funcionários substitutos, como por exemplo professores substitutos das instituições federais de Ensino Superior. É interessante notar que, da passagem do governo FHC para o primeiro mandato do governo Lula, os professores da Rede Federal foram responsáveis por um aumento vertiginoso no número de horas paradas. O número de Horas Paradas dos professores da Rede Federal de Ensino Superior passaram de 56 no último governo FHC para 1.416 no primeiro Lula. Os professores do Ensino Superior e Técnico aumentaram de 8 no segundo mandato FHC, para 1.264 entre os dois governos (como pode ser observado na Tabela 1 e 2).

A situação econômica melhorou para os países emergentes de 2003 até meados de 2008 o que fez com que a fosse possível a continuidade das linhas básicas da política macroeconômica que vinha sendo implementada desde 1999, o que levou a uma inflação menor e um crescimento do PIB.

Os investimentos diretos, aplicações no mercado financeiro e empréstimos externos compensaram o declínio do saldo na conta corrente tornando possível manter a acumulação de reservas internacionais. Assim, a ampliação de reservas não impediu a valorização do real (a partir de 2004), efeito que só foi revertido a partir da crise de 2008.

$\mathrm{O}$ crescimento foi favorecido pelo aumento do emprego formal, dos rendimentos do trabalho, das transferências de renda, do aumento real do salario mínimo, que segundo Baltar et al. (2010), resultaram em um aumento expressivo da renda das famílias, particularmente aquelas situadas em estratos intermediários ou menores de renda familiar. Um fator que favoreceu esse processo foi a ampliação do crédito ao consumo com elevação dos prazos, queda de juros nominais e com as mudanças institucionais que passaram a permitir o crédito com desconto direto na folha de pagamentos dos empregados assalariados.

Desde 1980 o produto industrial brasileiro tem crescido muito pouco, reduzindo sua participação na geração do PIB, de 34\% para 16\% de 1980 até 2005, o que inicia um período de semi-estagnação da economia brasileira em que o produto per capita quase não aumentou. A abertura comercial da década de 1990 não mudou esse quadro caracterizado pelo baixo dinamismo da indústria nacional e do crescimento do PIB, com taxas médias de expansão menores dos que a da década anterior.

Segundo eles (Baltar et. al. 2010), a partir do segundo mandato do presidente Lula torna-se mais clara uma diferença de posição de governo em relação ao crescimento econômico, apesar da continuidade da política macroeconômica focadas nas metas inflacionários, no superávit primário e na política de cambio de flutuante. Ressalto que esse cenário de crescimento econômico pode ser um fator determinante na maior incidência de greves, a medida que partimos da hipótese de que os líderes sindicais fazem greves quando percebem momentos oportunos para o ganho.

Um sintoma dessa mudança foi a recusa em aprofundar o ajuste fiscal ou recursar a implementação de uma política sugerida por economistas e por segmentos conservadores da sociedade. Tal política fiscal tinha como objetivo gerar um superávit nominal que contribuiria para cobrir a totalidade do pagamento do serviço da dívida pública, acelerando a queda na relação entre esta divida e o PIB.

Podemos destacar dois indicadores da mudança de posição do governo; em primeiro lugar o PAC (Plano de Aceleração do Crescimento) que foi lançado 
visando restaurar o quadro de pessoal e o nível dos salários dos funcionários públicos, que vinham sendo sacrificados por esforços anteriores de contenção das despesas públicas. Em segundo a capitalização do BNDES pelo Tesouro Nacional e a intensificação de sua atuação na articulação da formação de grupos empresarias nacionais e no apoio ao investimento das empresas estatais.

A reação do governo brasileiro a crise internacional de 2008 também expressa essa mudança de posição. O Banco Central diminuiu a taxa básica de juros brasileira (Selic), relaxou o depósito compulsório dos bancos e usou as reservas internacionais para garantir o financiamento das exportações. Além disso reduziu temporariamente o IPI (Imposto sobre Produtos Industrializados) dos bens duráveis de consumo e lançou um programa de construção de habitações populares. Reduziu também o imposto de Renda para a classe média e usou o banco público para garantir o atendimento da demanda de crédito e incorporar instituições financeiras fragilizadas pela crise. Tais mudanças são a expressão de uma nova postura do governo na condução da política econômica e a gestão dos impactos da crise internacional. Segundo Baltar et al. (2010), essa nova postura do governo em relação a crise internacional e a forma com que tem-se conduzido o debate sobre a construção institucional necessária para tirar proveito da extração de novas reservas petrolíferas tem levado a uma proximidade maior entre a esfera pública e a iniciativa privada.

A partir de 2007 o segundo mandato do presidente Lula foi marcado pela elevação das taxas médias de crescimento da economia brasileira momento em que o mercado de trabalho brasileiro apresentou mudanças significativas no que diz respeito a redução das taxas médias de desemprego, expansão do emprego assalariado formal (protegido por legislação trabalhista), crescimento do emprego nos setores mais organizados da economia, inclusive no setor público, elevação substantiva do valor real do salário mínimo e a recuperação dos valores reais dos salários negociados em convenções e acordos coletivos.

Apesar das formas de contratação verificadas na RAIS terem sido ampliadas de um, para nove modalidades de 1989 para 2008, os contratos temporários apresentam baixa incidência, representando somente $1,4 \%$ do total de empregados no setor privado. No setor público, especialmente na esfera municipal houve um aumento de contratações temporárias, entre 1995 e 2003 . No entanto, depois de 2003 verificou-se uma diminuição das contratações de funcionários demissíveis e temporários, especialmente na esfera federal, devido ao termo de ajuste de conduta entre o Ministério Público do Trabalho e o Governo
Central para a substituição desses servidores por concursados.

Assim, com exceção dos servidores públicos, não houveram avanços das contratações atípicas no Brasil. Em um momento de melhoramento da economia nacional, as instituições públicas e os sindicatos contribuíram para que as empresas contratassem conforme a legislação vigente. Podemos destacar também a necessidade de melhoria da arrecadação do Estado visando frear o crescente endividamento público; o papel das instituições públicas em especial aquelas responsáveis por fiscalizar e garantir o cumprimento da legislação social e trabalhista.

Ao longo dos anos 1990 prevaleceu uma tendência de fortalecer mecanismos de negociação direta e viabilizar soluções privadas dos conflitos trabalhistas. A partir de 1999 começaram a surgir mecanismos de controle e de fiscalização especialmente por meio de incentivos monetários vinculados ao pagamento de encargos e arrecadação de FGTS (Fundo de Garantia por Tempo de Serviço - prevê o recolhimento de 8\% do salário como uma forma de indenização caso seja despedido por justa causa). Nesse período houve uma melhoria no sistema de fiscalização o que pode explicar o avanço no emprego formal no período.

Apesar de ter-se mantido constante o emprego público ao longo da década de 1990, houve um aumento nos municípios, em escolas públicas e postos de saúde municipais, embora, o emprego gerado nesses casos apresentar um padrão inferior ao predominante no Governo Federal. Quanto ao governo federal, nos interessa ressaltar o aumento expressivo no número de horas paradas nas categorias destacadas acima. Durante o segundo governo FHC e primeiro Lula, a categoria dos funcionários da saúde federais e dos professores a rede federal de ensino, como pode ser observado nas Tabelas 1 e 2 .

Ao longo do governo Lula houve um esforço por parte do Governo Federal na recomposição de algumas carreiras públicas por meio da realização de concursos públicos, provocando assim um incremento nas contratações. Segundo dados do RAIS, o número de servidores públicos estatutários efetivos cresceu cerca de $25 \%$ entre 2003 e 2008 , ou seja, a administração pública nos três níveis de governo foi responsável pela contratação de 1,4 milhão de pessoas.

\section{Conclusão}

Neste artigo procuramos destacar e identificar aspectos referentes as greves do setor público federal brasileiro de 1995 a 2010. Os dados foram apresentados e analisados levando em consideração o cenário macro político brasileiro ou o "estado da arte" das relações de trabalho no Brasil, as mudanças ou reformas administrativas engendradas pelo governo 
FHC e a organização dos diversos segmentos sindicais ao longo do período, destacando o número de greves e horas paradas de cada categoria ao longo dos dois governos.

Ressaltamos também o caráter multilateral das relações de trabalho no setor público no Brasil e a natureza intrinsecamente política da interação entre os atores. Os dados mostraram que o governo FHC, empenhou-se na redução do efetivo de funcionários públicos do executivo civil, e um aumento do que chamamos de "carreiras estratégicas de estado", do judiciário e do legislativo, onde observou-se um aumento considerável ao longo dos dois mandatos. Esse período é também marcado por um baixo número de greves e horas paradas em um período em que não havia diálogo entre governo e os sindicatos e uma falta de mecanismos de negociação entre as partes. Destacamos que o processo de reforma administrativa engendrado pelo governo FHC, buscando disciplinar o emprego público, muda ou reforça a natureza política das relações de trabalho no setor público, a medida que condições econômicas empelem o governo a promover reforma e ajustes e corte de gastos, o que gera uma imprevisibilidade maior das relações entre os atores.

Os dados mostraram também que a partir de 2003 com o governo Lula, registrou-se um aumento abrupto do número de horas paradas e das greves, em um momento em que o governo estava primeiramente empenhado em repor ou aumentar o quantitativo de funcionários públicos do executivo civil e em estabelecer um diálogo com os sindicatos. A partir de 2003 iniciou-se um processo de negociação e tentativas de institucionalização da negociação coletiva no setor público brasileiro. O estabelecimento das mesas de negociação tornaram-se um canal de expressão das demandas da sociedade, fator que pode explicar em parte a alta incidência de greves no período.

Por fim é imprescindível destacar, quanto ao papel dos sindicatos e da negociação trabalhista, que as negociações coletivas a partir de 2004 começaram a apresentar resultados mais promissores para os trabalhadores. Segundo Baltar et al. (2010) a partir dessa data as negociações coletivas passaram a contribuir para a recuperação do poder de compra dos salários, tendência essa mantida no período de crise (2008/2009) em que grande parte da categoria de trabalhadores conseguiu recompor o poder de compra dos salários e muitas negociações incorporaram aumento real. Segundo eles, a melhora das negociação salariais está relacionada com a capacidade de representação dos sindicatos em um ambiente político e econômico favorável no país, marcado especialmente pela existência do crescimento econômico e de uma política de valorização do salario mínimo.
Além disso, um traço distinto nos últimos anos foi a adoção de uma agenda comum pelas principais centrais sindicais no Brasil. Entre eles podemos destacar: 1. Redução da jornada de trabalho para menos 40 horas semanais. Nesse sentido há um projeto de lei em tramitação no Congresso Nacional, além de que diversos sindicatos tem assinado acordos coletivos que estabelecem uma redução gradativa da jornada. 2. A regulamentação da terceirização está em pauta no Poder Legislativo desde os anos 1990, mas recentemente o debate tem incorporado a concepção de inibir as práticas de precarização do trabalho e de preservar os direitos trabalhistas e a proteção social. 3.A atual política de valorização do salario mínimo está em vigor desde 2011. 4. Em 2010, as principais centrais sindicais anunciaram que apresentarão uma plataforma com as suas principais propostas para a discussão de um projeto de desenvolvimento sustentável com distribuição de renda e valorização do trabalho, prevendo-se inclusive a realização de uma conferencia unitária.

Por fim, procuramos, neste artigo, destacar a natureza política das relações do setor público brasileiro, relacionando a incidência e a demora das greves com modelos de estado e com a falta de mecanismos institucionalizados de negociação coletiva. Os dados apresentados auxiliam no entendimento de que no Brasil as lideranças sindicais optam por fazer greves em momentos oportunos para o ganho e de que a maior demora das greves pode estar relacionada a falta de mecanismos institucionalizados de negociação. Dessa forma destacamos que as relações de trabalho no setor público não são um jogo de soma zero, onde a perda de um ator necessariamente implica no ganho de outro. A multiplicidade de atores e interesses envolvidos no processo negociativo e na votação dos acordos na esfera legislativa revela a complexidade dessa relação.

\section{Referências}

Abramo, Laís Wendel. 1986. O resgate da dignidade (a greve de 1978 em São Bernardo). Dissertação de Mestrado, Universidade de São Paulo. PMid:9897646.

Baltar, Paulo Eduardo de Andrade; Santos, Anselmo Luís dos; Krein, José Dari; Leone, Eugenia; Proni, Marcelo Weishaupt; Moretto, Amilton; Maia, Alexandre Gori e Salas, C. 2010. Trabalho no governo Lula: uma reflexão sobre a recente experiência brasileira. GLU - Global Labour University Working Papers. n. 9.

Birke, Peter. 2007. The persistence of labour unrest: Strikes. In S. Van der Velden, H. Dribbusch, D. Lyddon, K. Vandaele (eds.), Strikes around the world, 1968-2005. Case-studies of 15 countries. Amsterdam: Aksant, p. 156. 
Boletim Estatístico de Pessoal. 1995. Brasília, DF: Ministério do Planejamento, Orçamento e Gestão. v. 1 , janeiro.

Brasil. 1988. Constituição da República Federativa do Brasil. Brasília, DF: Senado Federal.

Brasil. Ministério do Trabalho. 1990. Lei no 8.036 de 11 de maio de 1990. Dispõe sobre o Fundo de Garantia do tempo de serviço, e dá outras providências. Diário Oficial da República Federativa do Brasil, Brasília, DF, 12 maio. Disponível em: <http://www.planalto. gov.br/ccivil_03/leis/18036consol.htm>.

Brasil. Ministério do Trabalho. 2000. Lei no 101 de 04 de maio de 2000. Estabelece as normas de finanças públicas voltadas para a responsabilidade na gestão fiscal e dá outras providências. Diário Oficial da República Federativa do Brasil, Brasília, DF, 5 maio. Disponível em: <http://www.planalto.gov.br/ ccivil_03/leis/lcp/lcp101.htm>.

Cheibub, Zairo Borges. 1999. Reforma Administrativa e Relações trabalhistas no setor público: dilemas e perspectivas. Cadernos ENAP, (18): 6-65

Costa, Frederico Lustosa da. 2008. História das Reformas Administrativas no Brasil. Narrativas, teorização e representações. Revista do Serviço Público, 59(3):271-288.

Dieese. 2005. O movimento grevista em 2004. Estudos e Pesquisas, (12): 2-39.

Ferner, Antony and Hyman, Richard. 1992a. Introduction: Industrial relations in the New Europe. In R. Hyman e A. Ferner (eds.), Industrial relations in the New Europe. Oxford: blackwell Business.

Ferner, Antony and Hyman, Richard. 1992b. Italy: Between Political Exchange and Micro-Corporatism. In A. Ferner e R. Hyman (eds.), Industrial Relations in the New Europe. Oxford: Blackwell Business, p. 156-201.

Locke, Richard. 1999. Sindicatos e Reforma Administrativa na Itália e EUA. Cadernos ENAP, (18): 66-77.
Nogueira, Roberto Pereira. 2005. Novas tendências internacionais da força de trabalho do setor público. O Brasil comparado com outros países. Brasília: NESP/CEAM/Unb.

Noronha, Eduardo Garuti. 2009. Ciclo de greves, transição política e estabilização: Brasil, 1978-2007. São Paulo: Lua Nova, n. 76.

Noronha, Eduardo Garuti. 1992. Greves na Transição Brasileira. Dissertaçã de Mestrado, Universidade Federal de Campinas. PMCid:PMC1554260.

Noronha, Eduardo Garuti and Gebrin, Vera. 1998. Explaining an exceptional wave of strikes: from authoritarian Brazil to democracy. Chicago, XXI International Congress.

Shalev, Michael and Korpi, Walter. 1979. Strikes, industrial relations and class conflict in capitalist societies. British Journal of Sociology. 30(2): 161-187.

Shalev, Michael and Korpi, Walter. 1980. Strikes, Power and Politics in Western Nations: 1900-1976. In Maurice Zeitlin (ed.), Political Power and Social Theory. Greenwich: JAI Press, p. 301-304.

Sussekind, Arnaldo. 1999. Direito Constitucional do Trabalho. Rio de Janeiro: Renovar.

Tilly, Charles. 1974. Strikes in France - 1830-1968. Londres: Cambridge University Press.

Tilly, Charles. 1978. From Mobilization to Revolution. Newberry Award Records. PMCid:PMC1541210.

Tsebellis, George. 1998. Jogos ocultos: escolha racional no campo da política comparada. São Paulo: EdUSP.

Zapata, Francisco.1986. El conflicto sindical en américa latina. El Colégio de México, Centro de Estudios Sociológicos. PMCid:PMC1453837.

Zapata, Francisco. 1987. Trabajadores y Sindicatos en América Latina. Secretaría de Educacíon Pública, Direcion General de Publicaciones y Medios.

Zapata, Francisco. 2007. Strikes in a state corporatism system Mexico. In S. Van der Velden, H. Dribbusch, D. Lyddon, K. Vandaele (eds.), Strikes around the world case studies of 15 coutries. Amsterdam: Aksant Academic Pubilshers, p. 202. 